\title{
PELAYANAN BANK SYARIAH SERTA PENGARUHNYA TERHADAP MINAT MAHASISWA (STUDI PADA MAHASISWA FAKULTAS SYARIAH DAN HUKUM UIN SUSKA RIAU)
}

\author{
Rozi Andrini \\ Fakultas Syariah dan Hukum, Unversitas Islam Negeri SUSKA RIAU \\ Email: rozi.andrini@uin-suska.ac.id
}

\begin{abstract}
ABSTRAK
Penelitian ini bertujuan untuk mengetahui pelayanan bank syariah serta pengaruhnya terhadap minat mahasiswa (studi pada mahasiswa Fakultas Syariah dan Hukum UIN Suska Riau). Kajian ini penting untuk melihat pelayanan Bank BRI Syariah dan pengaruh pelayanan terhadap minat menggunakan jasa Bank BRI Syariah pada mahasiswa Fakultas Syariah dan Hukum UIN Suska Riau. Adapun teknik pengumpulan data dalam penelitian ini menggunakan angket, observasi dan riset kepustakaan. Sedangkan metode analisis data menggunakan deskriptif kuantitatif. Jumlah sampel sebesar 352 nasabah dengan menggunakan metode simple random sampling. Hasil penelitian menunjukkan bahwa pelayanan yang baik sudah dilakukan oleh BRI Syariah dan disambut dengan reaksi positif oleh nasabah. Serta menunjukkan bahwa pelayanan berpengaruh positif terhadap minat menggunakan jasa Bank BRI Syariah pada mahasiswa Fakultas Syariah dan Hukum UIN Suska Riau.
\end{abstract}

Kata Kunci : Pelayanan, Minat, Bank Syariah.

\begin{abstract}
This study was aimed at knowing the services of Islamic banks and their influence on student interest (Study of Students in Sharia and Law Faculty of UIN Suska Riau). This study is important to look at BRI Sharia services and the effect of services on interest in using the services of BRI Sharia on students The Sharia and Law Faculty of UIN Suska Riau, the data collection techniques in this study used questionnaires, observation and library research, while the method of data analysis used quantitative descriptive. The number of samples was 352 customers using the simple random sampling method. Good practices have been conducted by BRI Sharia and welcomed with positive reactions by customers, and shows that service has a positive effect on the interest in using the services of BRI Sharia bank to students of the Sharia and Law Faculty of UIN Suska Riau.
\end{abstract}

Keywords : Service, Interest, Islamic Bank. 


\section{PENDAHULUAN}

Perekonomian menjadi sarana kehidupan utama yang perlu dikelola secara sistematis dan kreatif sesuai dengan kebutuhan manusia. Perkembangan dunia usaha dalam berbagai jenis industri, seakan-akan tak pernah berhenti karena bergeraknya zaman. Demikian juga dengan perkembangan industri perbankan. Dengan bergeraknya zaman dan adanya kebutuhan serta masukan dari masyarakat luas, perbankan yang ada saat ini banyak mengalami peningkatan yang cukup signifikan. Perkembangan ini diwujudkan dalam bentuk yang bervariasi baik dari segi inovasi produk, prinsip, sistem operasionalnya serta pergeseran paradigma.

Perbankan memiliki kedudukan yang sangat strategis, yakni sebagai penunjang kelancaran sistem pembayaran, pelaksanaan kebijakan moneter dan pencapaian stabilitas sistem keuangan, sehingga diperlukan perbankan yang sehat, transparan dan dapat dipertanggungjawabkan.

Bank sebagai lembaga keuangan merupakan suatu bidang usaha yang aset utamanya adalah uang. Kata bank itu sendiri berasal dari bahasa Latin banco yang artinya bangku atau meja. Pada abad ke- 12 kata banco merujuk pada meja, counter atau tempat penukaran uang (money changer). Dengan demikian, fungsi dasar bank adalah menyediakan tempat untuk menitipkan uang dengan aman dan menyediakan alat pembayaran untuk membeli barang dan jasa (Soemitra, 2010). Bank adalah sektor jasa yang profit oriented. Bank berperan penting dalam perkembangan perekonomian. Keberadaan bank merupakan lembaga pembiayaan untuk pembangunan perekonomian melalui dana pihak ketiga dan disalurkan pada pelaku ekonomi sehingga bisa menjalankan berbagai kegiatan usaha maupun kegiatan konsumsi. Jika dunia perbankan mengalami masalah maka akan mempengaruhi pembangunan perekonomian.

Sistem perbankan yang digunakan di Indonesia adalah dual banking system atau sistem perbankan ganda, di mana beroperasi dua jenis bank, yaitu bank konvensional dan bank syariah. Kemunculan bank syariah seiring dengan upaya gencar yang dilakukan oleh para pakar Islam dalam mendukung ekonomi Islam yang diyakini akan mampu mengganti dan memperbaiki sistem ekonomi konvensional yang berbasis pada bunga. Hal ini berbeda dengan konsep dan filosofi dengan bank konvensional yang menerapkan sistem bunga, bank syariah melarang penerapan bunga dalam semua transaksi perbankan karena termasuk kategori riba. Dalil yang melarang sistem riba terdapat dalam Alqur'an surat alBaqarah ayat 275.

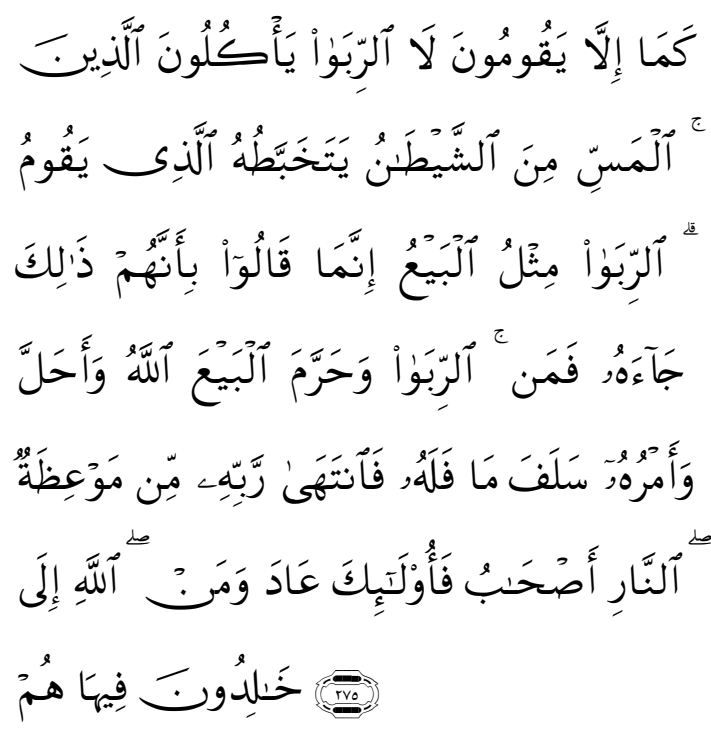

Artinya : "Orang-orang yang Makan (mengambil) riba tidak dapat berdiri melainkan seperti berdirinya orang yang kemasukan syaitan lantaran (tekanan) penyakit gila. Keadaan mereka yang demikian itu, adalah disebabkan mereka berkata (berpendapat), Sesungguhnya 
jual beli itu sama dengan riba, Padahal Allah telah menghalalkan jual beli dan mengharamkan riba. orang-orang yang telah sampai kepadanya larangan dari Tuhannya, lalu terus berhenti (dari mengambil riba), Maka baginya apa yang telah diambilnya dahulu (sebelum datang larangan); dan urusannya (terserah) kepada Allah. orang yang kembali (mengambil riba), Maka orang itu adalah penghuni-penghuni neraka; mereka kekal di dalamnya."

Bank Syariah adalah bank yang dalam aktivitasnya; baik dalam penghimpunan dana maupun dalam rangka penyaluran dananya memberikan dan mengenakan imbalan atas dasar prinsip syariah (Rodoni dan Hamid, 2008) dan menurut jenisnya terdiri atas bank umum syariah dan bank pembiayaan rakyat syariah. Prinsip syariah adalah prinsip hukum Islam dalam kegiatan perbankan berdasarkan fatwa yang dikeluarkan oleh lembaga yang memiliki kewenangan dalam penetapan fatwa di bidang syariah.

Awal mula munculnya perbankan syariah di Indonesia adalah didirikannya PT. Bank Muamalat Indonesia (BMI). Lahirnya Bank Muamalat Indonesia telah memicu pertumbuhan bank-bank syariah di Indonesia. terutama sejak diberlakukannya Undang-Undang Nomor 7 Tahun 1992 tentang Perbankan, yang kemudian direvisi dengan UndangUndang No. 10 tahun 1998 dan diperbaharui lagi dengan UndangUndang Nomor 21 Tahun 2008 tentang Perbankan Syariah, Maka bank syariah di Indonesia semakin memiliki landasan hukum yang memadai sehingga mendorong pertumbuhannya lebih pesat lagi.

Berdasarkan data statistik perbankan syariah yang dikeluarkan oleh Otoritas Jasa Keuangan (OJK), per Desember tahun 2019 total aset perbankan syariah sebesar Rp. 350.364 miliar. Jumlah dan jaringan kantor perbankan syariah juga mengalami perkembangan, dimana pada tahun 19921998 hanya ada 1 unit Bank Syariah, maka pada tahun 2019, jumlah Bank Syariah di Indonesia telah bertambah menjadi 34 unit, yang terdiri dari 14 Bank Umum Syariah dan 20 Unit Usaha Syariah.

Peningkatan pertumbuhan jumlah asset dan jumlah jaringan bank syariah yang ada di Indonesia menunjukkan minat masyarakat terhadap bank syariah ini sangat tinggi. Sehingga bank syariah perlu memperhatikan kebutuhan dan keinginan konsumen tersebut. Di Indonesia perkembangan bank syariah terus dilakukan dengan berbagai cara, salah satu upaya bank syariah dalam mengembangkan usahanya adalah dengan menjalin kerjasama dengan berbagai lembaga pendidikan di Indonesia. Seperti menjalin kerjasama dengan Universitas-universitas Islam yang ada di Indonesia. Bagi bank syariah kerjasama tersebut sangat penting karena selain bertujuan untuk meningkatkan profit perusahaan juga memperluas jaringan kerja. Tak terkecuali oleh bankbank syariah yang ada di Kota Pekanbaru. Universitas Islam Negeri Sultan Syarif Kasim Riau adalah salah satu lembaga pendidikan yang menjalin kerjasama dengan bank-bank syariah yang ada di kota Pekanbaru.

Menurut Mujahidin (2010) dalam Ekonomi Islam 2, peran yang bisa dimainkan mahasiswa dalam pengembangan ekonomi Islam adalah:

\section{Actor}

Artinya, mahasiswa semestinya menjadi pionir-pionir dalam praktik ekonomi Islam. Misalnya mahasiswa hanya menjual dan membeli barang dan jasa yang halal saja. Mengelola keuangan tanpa riba. 


\section{Educator}

Sebagai kelompok masyarakat terdidik, mahasiswa secara relatif lebih cepat memahami dan memiliki akses ke khasanah wacana ekonomi Islam ketimbang kelompok masyarakat lain.

\section{Motivator}

Pengkajian dan praktik ekonomi Islam di tengah sistem kapitalis bukanlah tindakan yang popular, terasa asing dan mudah menimbulkan rasa putus asa mengingat nature dari masyarakat memang tidaklah kompatibel dengan ekonomi Islam.

\section{Akselerator}

Mahasiswa harus menyadari bahwa sebesar apapun praktik dan setinggi apapun kesadaran masyarakat tentang ekonomi Islam di tengah sistem sekuler tetaplah belum merupakan wajah sesungguhnya dari keadaan yang sebenarnya bila ekonomi Islam diterapkan secara keseluruhan.

Jumlah mahasiswa yang besar tersebut seharusnya menjadi kekuatan serta peluang yang sangat besar bagi bank-bank syariah untuk terus berkembang, meningkatkan profit dan menunjukkan keunggulan mereka sebagai bank yang memberikan pelayanan sesuai dengan syariah Islam, mengingat mahasiswa merupakan kelompok yang memberikan pengaruh besar dalam masyarakat serta berperan sangat penting dalam perkembangan ekonomi syariah. Namun pada kenyataannya masih terdapat mahasiswa yang juga menggunakan jasa bank konvensional disamping mereka telah menjadi nasabah di bank syariah yang telah ditentukan oleh pihak Universitas dengan berbagai alasan.

\section{TINJAUAN PUSTAKA}

\section{Pelayanan}

Pelayanan merupakan rasa yang menyenangkan yang diberikan kepada orang lain disertai keramahan dan kemudahan dalam memenuhi kebutuhan mereka. Pelayanan diberikan sebagai tindakan atau perbuatan seseorang atau organisasi untuk memberikan kepuasan kepada pelanggan atau nasabah. tindakan tersebut dapat dilakukan melalui cara langsung melayani pelanggan (Kasmir, 2005).

Kotler (2007) mendefinisikan pelayanan (jasa) sebagai setiap tindakan atau kinerja yang dapat ditawarkan satu pihak kepada pihak lain yang pada dasarnya tidak berwujud dan tidak mengakibatkan kepemilikan sesuatu. Pelayanan merupakan perilaku produsen dalam rangka memenuhi kebutuhan dan keinginan konsumen. Kotler juga mengatakan bahwa perilaku tersebut dapat terjadi pada saat, sebelum dan sesudah terjadinya transaksi. Pada umumnya pelayanan yang bertaraf tinggi akan menghasilkan kepuasan yang tinggi serta pembelian ulang yang lebih sering.

Menurut Tjiptono (2005), pelayanan adalah tindakan atau perbuatan seseorang atau organisasi untuk memberikan kepuasan kepada pelanggan. Pelayanan adalah sebuah produk yang ditawarkan dan disampaikan kepada pelanggan yang membutuhkan secara luas mencakup baik yang kelihatan (tangibles) maupun yang tidak kelihatan (intangibles).

Jadi pelayanan dapat didefinisikan sebagai tindakan atau kinerja yang menciptakan manfaat bagi pelanggan dengan mewujudkan perubahan yang diinginkan dalam diri atau atas nama penerima. Sehingga pelayanan itu sendiri memiliki nilai tersendiri bagi pelanggan dalam 
hubungannya dengan menciptakan nilainilai pelanggan.

Terdapat lima dimensi pokok yang berkaitan dengan kualitas pelayanan jasa, yaitu: 1) Tangible (bukti fisik) 2) Reliability (keandalan), 3) Responsiveness (daya tanggap), 4) Assurance (jaminan) dan 5) Empathy (empati) (Tjiptono, 2005). Kualitas pelayanan yang terdiri dari 5 unsur tersebut dan dapat dilakukan dengan baik dipastikan akan terekam di dalam memori pengguna jasa selanjutnya dipastikan untuk diceritakan kepada orang lain sehingga segala informasi yang diberikan oleh pihak bank juga ikut diceritakan oleh pengguna jasa yang merasa puas terhadap kualitas pelayanan.

Harapan dari kepuasan pelanggan yang bercerita kepada orang lain adalah menjadikan orang lain juga meningkat pengetahuannya (walaupun orang lain tersebut kemungkinan sudah mengetahui dari informasi yang disediakan oleh bank melalui media massa atau lainnya) terhadap bank tersebut dan akhirnya orang tersebut semakin berminat untuk menggunakan jasa bank itu, baik melakukan kredit, menabung, dan transaksi bank lainnya.

Zeithaml et all

mengungkapkan bahwa kualitas pelayanan (jasa) dikelompokkan ke dalam 5 dimensi oleh Parasuraman, yaitu:

1. Bukti Langsung (Tangible), yaitu: sebagai fasilitas yang dapat dilihat dan di gunakan perusahaan dalam upaya memenuhi kepuasan pelanggan, seperti gedung kantor, peralatan kantor, penampilan karyawan dan lain-lain.

2. Keandalan (Reliability), yaitu: kemampuan memberikan pelayanan kepada pelanggan sesuai dengan yang diharapkan, seperti kemampuan dalam menepati janji, kemampuan memecahkan masalah dan kemampuan untuk meminimumkan kesalahan.

3. Daya Tanggap (Responsiveness), yaitu: sebagai sikap tanggap, mau mendengarkan dan merespon pelanggan dalam upaya memuaskan pelanggan, misalnya: mampu memberikan informasi secara benar dan tepat, tidak menunjukkan sikap sok sibuk dan mampu memberikan pertolongan dengan segera.

4. Jaminan (Assurance), yaitu: kemampuan karyawan dalam menimbulkan kepercayaan dan keyakinan pelanggan melalui pengetahuan, kesopanan serta menghargai perasaan pelanggan.

5. Kepedulian/Empati (Emphaty), yaitu: kemampuan atau kesediaan karyawan memberikan perhatian yang bersifat pribadi, seperti bersikap ramah, memahami kebutuhan dan peduli kepada pelanggannya.

Salah satu cara agar penjualan jasa suatu perusahaan lebih unggul dibandingkan para pesaingnya adalah dengan memberikan pelayanan yang berkualitas dan bermutu, yang memenuhi tingkat kepentingan konsumen. Tingkat kepentingan konsumen terhadap jasa yang akan mereka terima dapat dibentuk berdasarkan pengalaman dan saran yang mereka peroleh. Konsumen memilih pemberi jasa berdasarkan peringkat kepentingan. Dan setelah menikmati jasa tersebut mereka cenderung akan membandingkannya dengan yang mereka harapkan (Rangkuti, 2002).

Bila jasa yang mereka nikmati ternyata berada jauh di bawah jasa yang mereka harapkan, para konsumen akan 
kehilangan minat terhadap pemberi jasa tersebut. Sebaliknya jika jasa yang mereka nikmati memenuhi atau melebihi tingkat kepentingan, mereka akan cenderung memakai kembali produk jasa tersebut.

Tingkat kualitas pelayanan tidak dapat diniai berdasarkan sudut pandang perusahaan tetapi harus dipandang dari sudut pandang penilaian pelanggan. Karena itu, dalam merumuskan strategi dan program pelayanan, perusahaan harus berorientasi pada kepentingan pelanggan dengan memperhatikan komponen kualitas pelayanan.

Dalam bank syariah pelayanan merupakan upaya yang harus dilakukan untuk memenuhi kepuasan nasabahnya. Dalam pelayanan yang diberikan kepada nasabah akan menjadi tolak ukur sejauhmana pihak bank mampu memberikan yang terbaik kepada setiap nasabahnya. Bagi bank syariah pelayanan harus sesuai dengan syariah Islam yang telah ditetapkan. Pelayanan adalah upaya yang dilakukan secara langsung ataupun tidak langsung dalam menganalisis yang bersifat menyeluruh. Dalam pelayanan yang berlaku pada kegiatan perbankan analisisnya dapat meliputi aspek sebagai berikut : penentu kegiatan perbankan dan faktor-faktor yang mempengaruhinya, masalah transaksi dan pengawasan operasional bank dari sudut syariahnya, bentukbentuk kebijakan yang dibuat dalam mengahadapi masalah yang timbul.

Jadi dari beberapa teori yang ada kesimpulannya bahwa pelayanan merupakan salah satu faktor yang dapat mempengaruhi kepuasan pelanggan. Sehingga pelanggan yang merasa puas dengan pelayanan suatu perusahaan akan menunjukkan minat terhadap perusahaan tersebut.

Hubungan
disepakati adalah $\begin{array}{r}\text { banyak } \\ \text { bahwa kepuasan }\end{array}$

membantu pelanggan dalam merevisi persepsinya terhadap kualitas jasa (pelayanan). Dasar pemikirannya antara lain: (1) Bila konsumen tidak memiliki pengalaman sebelumnya dengan suatu perusahaan, maka persepsinya terhadap kualitas pelayanan perusahaan tersebut akan didasarkan pada ekspektasinya; (2) Interaksi (service encounter) berikutnya dengan perusahaan tersebut akan menyebabkan konsumen memasuki proses diskonfirmasi dan merevisi persepsinya terhadap kualitas pelayanan; (3) Setiap interaksi tambahan dengan perusahaan itu akan memperkuat atau sebaliknya malah mengubah persepsi pelanggan terhadap kualitas pelayanan; dan (4) Persepsi terhadap kualitas pelayanan yang telah direvisi memodifikasi minat beli konsumen terhadap perusahaan di masa yang akan datang.

\section{Minat}

Dalam kamus bahasa Indonesia memiliki makna kecenderungan hati yang tinggi terhadap sesuatu. Secara sederhana, minat (interest) berarti kecendrungan dan kegairahan yang tinggi atau keinginan yang besar terhadap sesuatu (Syah, 2006). Pada umumnya disertai dengan perasaan senang akan sesuatu itu (Djatsidi, 2010).

Menurut Abu Ahmadi minat adalah sikap jiwa seorang termasuk ketiga fungsi jiwanya (kognisi, konasi, dan emosi), yang tertuju pada sesuatu, dan dalam hubungan itu unsur perasaan yang terkuat (Abu, 2009). Sedangkan Menurut Mappiare (1997) ialah suatu perangkat mental yang terdiri dari suatu campuran dari perasaan, harapan, pendirian, prasangka atau kecenderungan lain yang mengarahkan individu kepada suatu pilihan tertentu.

Dari beberapa definisi minat di atas dapat ditarik kesimpulan, bahwa minat merupakan sikap seseorang yang 
mempunyai keinginan yang tinggi terhadap sesuatu atau suatu rasa kemauan yang kuat untuk melakukan suatu hal untuk mencapai tujuan tertentu. Peneliti mengambil dari pengertian minat adalah sikap jiwa orang seorang termasuk ketiga fungsi jiwanya (kognisi, konasi, dan emosi), yang tertuju pada sesuatu, dan dalam hubungan itu unsur perasaan yang terkuat.

Berikut ini penjelasan mengenai ketiga indikator yang dijadikan acuan terbentuknya minat nasabah, yaitu sebagai berikut:

a. Kognisi (Gejala pengenalan) : Kegiatan atau proses memperoleh pengetahuan (termasuk kesadaran, perasaan, dsb) atau usaha mengenali sesuatu melalui pengalaman sendiri.

b. Konasi (kemauan) : Merupakan salah satu fungsi hidup kejiwaanmanusia, dapat diartikan sebagai aktifitas psikis yang aktif dan berhubungan dengan pelaksanaan suatu tujuan.

c. Emosi : Kecenderungan untuk memiliki perasaan yang khas bila berhadapan dengan objek tertentu dalam lingkungannya.

Pada umumnya perbuatan kita sehari-hari disertai oleh perasaanperasaan tertentu, yaitu perasaan senang atau tidak senang.Perasaan senang atau tidak senang yang selalu menyertai perbuatan kita sehari-hari disebut warna efektif.

\section{Faktor-faktor yang Mempengaruhi Minat}

Menurut Hadinot (1998), ada dua faktor yang mempengaruhi minat seseorang yaitu:

1. Faktor dari dalam (intrinsik), yaitu berarti bahwa sesuatu perbuatan memang diinginkan karena seseorang senang melakukannya. Di sini minat datang dari diri orang itu sendiri. Orang tersebut senang melakukan perbuatan itu demiperbuatan itu sendiri.

2. Faktor dari luar (ekstrinsik), yaitu berarti bahwa sesuatu perbuatan dilakukan atas dasar dorongan atau pelaksanaan dari luar. Orang melakukan kegiatan ini karena ia didorong atau dipaksa dari luar.

Minat yang terjadi dalam individu dipengaruhi dua faktor yang menentukan, yaitu faktor keinginan dari dalam dan faktor keinginan dari luar. Minat dari dalam terdiri dari tertarik atau rasa senang pada kegiatan, perhatian terhadap suatu kegiatan dan adanya aktivitas atau tindakan akibat rasa senang maupun perhatian. Dengan demikian dapat disimpulkan bahwa secara garis besar minat dipengaruhi oleh dua faktor yaitu faktor yang berasal dari dalam diri individu itu sendiri (faktor intrinsic) dan faktor yang berasal dari luar individu tersebut) faktor eksrinsic).

\section{Minat Menggunakan Jasa dalam Pandangan Islam}

Dalam Islam, perilaku seorang konsumen harus mencerminkan hubungan dirinya dengan Allah SWT. Inilah yang tidak kita dapati dalam ilmu perilaku konsumsi konvensional. Setiap pergerakan dirinya, yang terbentuk belanja sehari-hari, tidak lain adalah manifestasi zikir dirinya atas nama Allah SWT. Dengan demikian, dia lebih memilih jalan yang dibatasi Allah SWT dengan tidak memilih barang haram, tidak kikir, dan tidak tamak supaya hidupnya selamat baik di dunia maupun di akhirat (Muflih, 2006).

Dalam menjelaskan pilihan konsumen pada ekonomi konvensioanal, konsumen cenderung memilih untuk 
memperoleh kepuasan (utility) dalam kegiatan konsumsinya. Sedangkan dalam ekonomi Islam, yang menjadi tujuan dari kegiatan konsumsinya adalah kecenderungan untuk mendapatkan kemaslahatan.

\section{METODE PENELITIAN}

Jenis Penelitian yang digunakan adalah penelitian lapangan (field research), dengan menggunakan pendekatan kuantitatif. Analisis ini digunakan untuk melihat pengaruh pelayanan terhadap minat menggunakan jasa.

\section{Populasi dan Sampel Penelitian}

Populasi dalam penelitian ini adalah nasabah Bank BRI Syariah (Mahasiswa Fakultas Syariah dan Hukum yang aktif) yang berjumlah 4.305 orang. Sedangkan sampel adalah bagian dari populasi yang penulis ambil untuk mewakili populasi secara keseluruhan sebagai responden. Metode yang digunakan adalah simple random sampling. Ukuran sampel dalam penelitian ini ditentukan dengan menggunakan rumus dari Isaac dan Michael berdasarkan tingkat kesalahan $5 \%$ yaitu 352 orang.

$$
\begin{gathered}
\mathrm{S}=\frac{\lambda^{2} \cdot \mathrm{N} \cdot \mathrm{P} \cdot \mathrm{Q}}{\mathrm{d}^{2}(\mathrm{~N}-1)+\lambda^{2} \cdot \mathrm{P} \cdot \mathrm{Q}} \\
\mathrm{S}=\frac{3,841 \times 4305 \times 0,5 \times 0,5}{0,05^{2}(4305-1)+3,841 \times 0,05 \times 0,05} \\
\mathrm{~S}=352 \\
\text { jadi jumlah sampel }=352
\end{gathered}
$$

\section{HASIL DAN PEMBAHASAN}

Dari hasil parsial untuk pelayanan diperoleh nilai $t$ hitung $(8,862)>t$ tabel $(1,97)$ sehingga hipotesis nol (Ho) ditolak dan hipotesis alternatif (Ha) diterima. Dengan ditolaknya Ho berarti pelayanan berpengaruh secara signifikan terhadap minat menggunkan jasa Bank BRI Syariah pada mahasiswa Fakultas Syariah dan Hukum UIN Suska Riau. Sehingga apabila pelayanan Bank BRI Syariah meningkat maka minat menggunakan jasa Bank BRI Syariah pada mahasiswa Fakultas Syariah dan Hukum UIN Suska Riau akan mengalami peningkatan.

Hasil ini dapat menerima teori yang dikemukakan oleh Rangkuty (2002). Bila jasa yang mereka nikmati ternyata berada jauh di bawah jasa yang mereka harapkan, para konsumen akan kehilangan minat terhadap pemberi jasa tersebut. Sebaliknya jika jasa yang mereka nikmati memenuhi atau melebihi tingkat kepentingan, mereka akan cenderung memakai kembali produk jasa tersebut. Artinya pelayanan mempengaruhi minat dalam menggunakan jasa.

Penelitian ini juga sejalan dengan penelitian terdahulu oleh Chotimah (2014) yang menyatakan bahwa faktor pelayanan bank syariah berpengaruh signifikan terhadap keputusan masyarakat dalam memilih bank syariah.

Pelayanan (jasa) sebagai setiap tindakan atau kinerja yang dapat ditawarkan satu pihak kepada pihak lain yang pada dasarnya tidak berwujud dan tidak mengakibatkan kepemilikan sesuatu (Kotler, 2007). Dalam pengembangan selanjutnya pada tahun 1990, kualitas pelayanan (jasa) dikelompokkan ke dalam 5 dimensi oleh Parasuraman, yaitu:

1. Bukti Langsung (Tangible), yaitu: sebagai fasilitas yang dapat dilihat dan di gunakan perusahaan dalam upaya memenuhi kepuasan pelanggan, seperti gedung kantor, 
peralatan kantor, penampilan karyawan dan lain-lain.

2. Keandalan (Reliability), yaitu: kemampuan memberikan pelayanan kepada pelanggan sesuai dengan yang diharapkan, seperti kemampuan dalam menepati janji, kemampuan memecahkan masalah dan kemampuan untuk meminimumkan kesalahan.

3. Daya Tanggap (Responsiveness), yaitu: sebagai sikap tanggap, mau mendengarkan dan merespon pelanggan dalam upaya memuaskan pelanggan, misalnya: mampu memberikan informasi secara benar dan tepat, tidak menunjukkan sikap sok sibuk dan mampu memberikan pertolongan dengan segera.

4. Jaminan (Assurance), yaitu: kemampuan karyawan dalam menimbulkan kepercayaan dan keyakinan pelanggan melalui pengetahuan, kesopanan serta menghargai perasaan pelanggan.

5. Kepedulian/Empati (Emphaty), yaitu: kemampuan atau kesediaan karyawan memberikan perhatian yang bersifat pribadi, seperti bersikap ramah, memahami kebutuhan dan peduli kepada pelanggannya.

Pelayanan merupakan hal yang sangat penting, setiap perusahaan memerlukan service excellence, yaitu suatu cara karyawan dalam melayani nasabah secara memuaskan. Mengenai pelayanan dalam hubungan bisnis, Islam mengetahui bahwa pelayanan harus diberikan dengan kualitas terbaik. Pelayanan yang berkualitas adalah apabila yang dikerjakan oleh seseorang untuk orang lain menimbulkan rasa senang yang berimplikasi baik terhadap hubungan antara kedua belah pihak yang berbisnis. Karena dalam berbisnis tidak hanya untuk keuntungan semata tetapi terdapat nilai keberkahan. Sebaiknya Bank BRI Syariah meningkatkan kualitas pelayanan kepada nasabah agar minat nasabah untuk menggunakan jasa Bank BRI Syariah semakin meningkat.

\section{KESIMPULAN}

Berdasarkan analisis yang telah dilakukan menggunakan alat analisis SPSS (Statistical Package for Social Science) versi 20 dapat disimpulkan Hasil pengujian secara parsial diketahui variabel pelayanan berpengaruh secara signifikan terhadap minat menggunakan jasa Bank BRI Syariah Sehingga apabila pelayanan yang diberikan meningkat maka minat menggunakan jasa Bank BRI Syariah pada mahasiswa Fakultas Syariah dan Hukum UIN Suska Riau akan mengalami peningkatan.

Untuk meningkatkan minat nasabah dalam menggunakan jasa bank BRI Syariah maka diharapkan senantiasa harus mampu memberikan pelayanan yang memuaskan nasabah. Pelayanan yang ditawarkan kepada nasabah dengan cara menambah jumlah kantor pelayanan, menambah jumlah ATM, menambah fitur-fitur pada aplikasi online. Meningkatkan sosialisasi kepada masyarakat untuk meningkatkan kualitas pelayanan bank syariah.

\section{DAFTAR PUSTAKA}

Abu, Ahmadi. 2009. Psikologi Umum. Rineka Cipta. Jakarta.

Chotimah, Chusnul. 2014. Pengaruh Produk, Pelayanan, Promosi dan Lokasi terhadap Masyarakat Memilih Bank Syariah di Surakarta. Naskah Publikasi Program Studi Akuntansi Fakultas Ekonomi dan Bisnis 
2020, Jurnal Tabarru' : Islamic Banking and Finance 3 (1) : 20 - 29

Universitas Muhammadiyah Surakarta.

Djatsidi, Indra. 2010. Мепијu Masyarakat Belajar. Paramadina. Jakarta.

Hadinoto, Siti Rahayu. 1998. Psikologi Perkembangan. Gadjah Mada University Press. Yogyakarta.

Kasmir. 2005. Bank dan Lembaga Keuangan Lainnya. PT RajaGrafindo Persada. Jakarta.

Kotler, Philip. 2007. Manajemen Pemasaran. Edisi Kedua Belas. Indeks. Jakarta.

Mappiare, Andi. 1997. Psikologi Remaja. Usaha Nasional. Surabaya.

Muflih, Muhammad. 2006. Perilaku Konsumen Dalam Perspektif Ilmu Ekonomi Islam. Raja Grafindo Persada. Jakarta.

Mujahidin, Akhmad. 2010. Ekonomi Islam 2. Al-Mujtahadah. Riau.

Rangkuti, Freddy. 2002. Measuring Customer Satisfaction. Penerbit PT. Gramedia Pustaka Utama, Jakarta.

Rodoni, Ahmad \& Hamid, Abdul. 2008. Lembaga Keuangan Syariah. Zikrul Hakim. Jakarta.

Soemitra, Andri. 2009. Bank \& Lembaga Keuangan Syariah. Kencana. Jakarta.

Syah, Muhibbin. 2006. Psikologi Pendidikan dengan Pendekatan Baru. Remaja Rosdakarya. Bandung.
Tjiptono, Fandy. 2005. Strategi Pemasaran. Andi Offset. Yogyakarta.

Zeithaml. dkk. 2010. Service Marketing. Mc. Graw Hill Inc. Int'l Edition. New York. 